\title{
XRD Characterization of AIN Thin Films Prepared by Reactive RF-Sputter Deposition
}

\author{
N. Matsunami ${ }^{1}$, H. Kakiuchida ${ }^{2}$, M. Sataka ${ }^{3}$, S. Okayasu ${ }^{3}$ \\ ${ }^{1}$ Energy Science Division, EcoTopia Science Institute, Nagoya University, Nagoya, Japan \\ ${ }^{2}$ National Institute of Advanced Industrial Science and Technology (AIST), Nagoya, Japan \\ ${ }^{3}$ Japan Atomic Energy Agency (JAEA), Tokai, Japan \\ Email: n-matsunami@nucl.nagoya-u.ac.jp
}

Received January 22, 2013; revised March 10, 2013; accepted April 18, 2013

Copyright (C) 2013 N. Matsunami et al. This is an open access article distributed under the Creative Commons Attribution License, which permits unrestricted use, distribution, and reproduction in any medium, provided the original work is properly cited.

\begin{abstract}
AlN thin films have been grown on $\mathrm{R}((1-12)$ surface-cut $)-\mathrm{Al}_{2} \mathrm{O}_{3}, \mathrm{SiO}_{2}$-glass and $\mathrm{C}((001)$ surface-cut $)-\mathrm{Al}_{2} \mathrm{O}_{3}$ substrates, by using a reactive-RF-sputter-deposition method. X-ray diffraction (XRD) shows that AlN film has (110) orientation of wurtzite crystal structure for $\mathrm{R}-\mathrm{Al}_{2} \mathrm{O}_{3}$ and (001) orientation for $\mathrm{SiO}_{2}$-glass and $\mathrm{C}-\mathrm{Al}_{2} \mathrm{O}_{3}$ substrates. The film thickness was analyzed by Rutherford backscattering spectroscopy (RBS) and it appears that XRD intensity does not show a linear increase with the film thickness but a correlation with the stress, i.e., deviation of the lattice parameter of the film from that of bulk. The film composition and impurities have been analyzed by ion beam techniques. Effects of highenergy ion beams are briefly presented on atomic structure (whether stress relaxation occurs or not), surface morphology and optical properties.
\end{abstract}

Keywords: Aluminum Nitride Film; Composition; Impurities; Atomic Structure; Surface Morphology; Optical Properties

\section{Introduction}

It has been known that aluminum nitride (AIN) has a wide direct-bandgap $(6.2-5.8 \mathrm{eV})[1,2]$ with hexagonalwurtzite crystal structure [3] and unique properties: good thermal conductivity $(\sim 3 \mathrm{~W} / \mathrm{cmK}$ at $300 \mathrm{~K})$ [4], good insulator $\left(>10^{11} \Omega \cdot \mathrm{cm}\right)$ [5], high dielectric constant [6], relatively small linear-expansion coefficients (5.3 and 4.2 $\times 10^{-6} \mathrm{~K}^{-1}$ along a- and c-axis) [7], high sound velocity $(6 \mathrm{~km} / \mathrm{s})$ [8] and large hardness [9]. Owing to these properties, AlN films have potential applications to electronic devices [10], surface acoustic wave (SAW) devices [11], actuator [12], transparent hard coatings and AlN composites to light-emitting devices [13]. Also, AlN films have been used as buffer layer for $\mathrm{GaN}$ [14] and $\mathrm{ZnO}$ [15] film growth. For these applications, X-ray diffraction (XRD) technique have been extensively employed to evaluate the crystalline quality and growth orientation of AlN films which have been grown by various techniques, chemical-vapor atomic-layer deposition (a special type of CVD) [2], metal organic CVD [16], molecular beam epitaxy [17], ion beam enhanced deposition (electron beam evaporation of $\mathrm{Al}$ combined with $\mathrm{N}$ ion bombardment) [5], reactive radio-frequency (RF) magnetron sputtering deposition [6,10,18], pulsed laser deposition (PLD) [19] on various substrates, sapphire [2,19], Si [5,14-16,18], $\mathrm{SiC}$ [17], Al [6], Mo [12] etc. For AlN films grown on $\mathrm{Si}(111)$, the authors have shown that oxygen impurities near the substrate surface affect the growth orientation and suggest that the XRD intensity decreases with increasing the stress and nearly diminishes when the stress exceeds $2 \%$, irrespective of the film thickness (27 - 470 $\mathrm{nm})$ [20]. Here, the stress is defined as the difference of the lattice parameters between film and bulk. Use of the stress can be justified based on the fact that c-axis length increases with the residual-stress [18] and temperature dependence of the lattice parameter is similar to that of the residual-stress in terms of pressure [19]. The result does not agree with the lattice relaxation around $50 \mathrm{~nm}$ of AlN on $\mathrm{SiC}$ [17] and favors the constant stress throughout the AlN film on $\mathrm{Si}(111)$ [16]. It is of interest to study whether the suggested stress is useful for the quality evaluation of AlN film grown on different substrates other than $\mathrm{Si}(111)$.

In this paper, we have grown AlN on R-plane cut sapphire $\left(\mathrm{R}-\mathrm{Al}_{2} \mathrm{O}_{3}\right), \mathrm{SiO}_{2}$-glass and $\mathrm{C}$-plane cut sapphire $\left(\mathrm{C}-\mathrm{Al}_{2} \mathrm{O}_{3}\right)$ substrates by a reactive RF-sputter deposition method. We have measured XRD, the composition, thick- 
ness and impurities, and examined use of the stress for the film quality evaluation. We also have measured surface morphology (grain size, shape and surface smoothness), which may affect the crystalline quality, since films are polycrystalline, and optical absorption. These properties might be important for applications mentioned above. For $\mathrm{AlN}$ on $\mathrm{R}-\mathrm{Al}_{2} \mathrm{O}_{3}$, irradiation with high-energy (90 MeV Ni) ions was performed in order to study whether stress relaxation, surface smoothing and bandgap modification occur or not by ion irradiation.

\section{Experimental}

AlN films were grown on $\mathrm{R}-\mathrm{Al}_{2} \mathrm{O}_{3}, \mathrm{SiO}_{2}$-glass and C$\mathrm{Al}_{2} \mathrm{O}_{3}$ substrates by using a reactive-RF-sputter-deposition method with $\mathrm{Al}$ target (purity of $99.999 \%$ ) in pure $\mathrm{N}_{2}$ gas of $\sim 0.3 \mathrm{~Pa}$ with a method described in [20,21]. A reason for usage of pure $\mathrm{N}_{2}$ gas is to avoid Ar inclusion into films, considering that conventionally $\mathrm{Ar}$ and $\mathrm{N}_{2}$ mixture gas has been employed. The substrates were subjected to ultrasonic rinse in ethanol prior to the film deposition. XRD with $\mathrm{Cu}-\mathrm{k} \alpha$ radiation was performed to examine crystalline quality and orientation. The thickness, composition and impurities of films were analyzed by RBS. The growth rate was obtained to be approximately $3 \mathrm{~nm} / \mathrm{min}$ for AlN on three substrates used in this study. Light impurities such as carbon and oxygen near the film surface were analyzed by using nuclear reaction analysis (NRA), ${ }^{12} \mathrm{C}(\mathrm{d}, \mathrm{p}){ }^{13} \mathrm{C}$ and ${ }^{16} \mathrm{O}(\mathrm{d}, \alpha){ }^{14} \mathrm{~N}$ with 1.2 $\mathrm{MeV} d$ at the reaction angle of $160^{\circ}$ [20]. In RBS and NRA, stopping powers are taken after [22] with the AIN density of $3.26 \mathrm{~g} \cdot \mathrm{cm}^{-3}\left(4.8 \times 10^{22} \mathrm{Al} \mathrm{cm}\right)$. Surface morphology was observed by atomic force microscopy (AFM) and optical absorption was measured by using a conventional spectrometer. Irradiation with $90 \mathrm{MeV} \mathrm{Ni}$ ions was performed by using a TANDEM accelerator at Japan Atomic Energy Agency at Tokai.

\section{Results and Discussion}

\subsection{Characterization}

Figure 1 shows XRD patterns and rocking curves of AlN film on $\mathrm{R}-\mathrm{Al}_{2} \mathrm{O}_{3}, \mathrm{SiO}_{2}$ and $\mathrm{C}-\mathrm{Al}_{2} \mathrm{O}_{3}$ substrate. The substrate temperature $\mathrm{T}_{\mathrm{s}}$ was optimized, $150^{\circ} \mathrm{C}, 200^{\circ} \mathrm{C}$ and $200^{\circ} \mathrm{C}$ for these substrates, respectively so that the XRD peak intensity is maximized and the full-width at halfmaximum (FWHM) of XRD rocking curve is minimized. It is found that AlN film has exceptionally a-axis, i.e.,

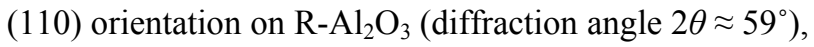
in contrast to c-axis $\left(2 \theta \approx 36^{\circ}\right)$, i.e., $(001)$ orientation grown on other substrates, $\mathrm{Si}, \mathrm{SiO}_{2}, \mathrm{C}-\mathrm{Al}_{2} \mathrm{O}_{3}$ etc. $\mathrm{FWHM}$ of the rocking curve of as-deposited film on $\mathrm{R}-\mathrm{Al}_{2} \mathrm{O}_{3}$ is order of $2^{\circ}$ (Figure 1(a) and Table 1). AlN on $\mathrm{SiO}_{2}$ glass-substrates has (001) orientation and FWHM is much larger $\left(\sim 10^{\circ}\right)$ (Figure 1(b) and Table 2). FWHM
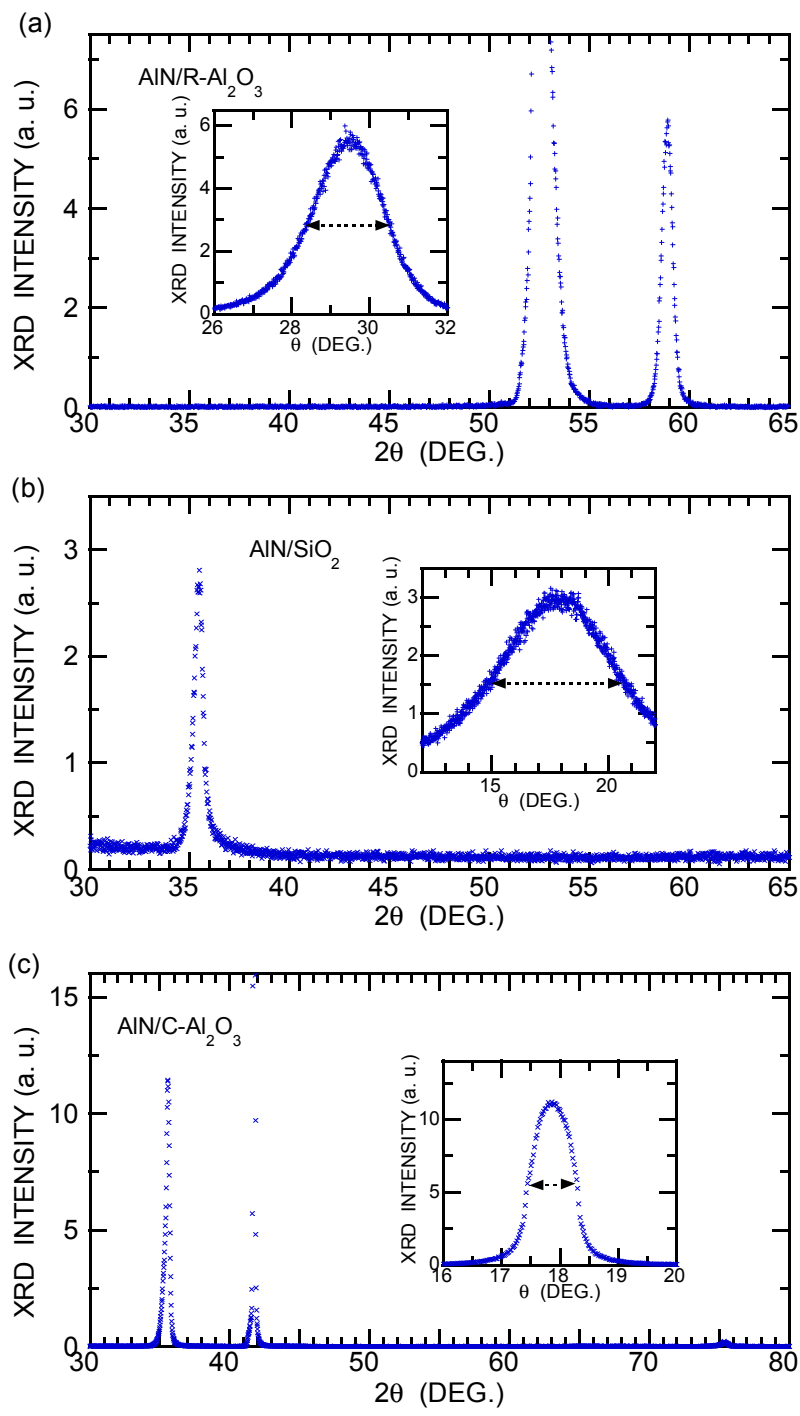

Figure 1. XRD patterns of as-deposited AIN film on R$\mathrm{Al}_{2} \mathrm{O}_{3}$ (a), $\mathrm{SiO}_{2}$ (b) and $\mathrm{C}-\mathrm{Al}_{2} \mathrm{O}_{3}$ (c) substrates. Rocking curves of as-deposited films are shown in the inset and FWHM is indicated by horizontal lines. Deposition time was 55, 30 and 30 min for $\mathrm{AIN}$ on $\mathrm{R}_{-} \mathrm{Al}_{2} \mathrm{O}_{3}, \mathrm{SiO}_{2}$ (sample 70c in Table 2) and $\mathrm{C}-\mathrm{Al}_{2} \mathrm{O}_{3}$. Peaks at $2 \theta \approx 59^{\circ}$ and $36^{\circ}$ are (110) and (002) diffraction of $\mathrm{AIN}$, and $52.5^{\circ}$ and $41.7^{\circ} \mathrm{R}$ - and C-plane of sapphire.

of the rocking curve of as-deposited film on $\mathrm{C}-\mathrm{Al}_{2} \mathrm{O}_{3}$ is order of $0.5^{\circ}$ (Figure 1(c)). Hence, the crystalline quality of $\mathrm{AlN}$ on $\mathrm{SiO}_{2}$-glass is poorer than that on $\mathrm{R}-\mathrm{Al}_{2} \mathrm{O}_{3}$ and is the best for $\mathrm{AlN}$ on $\mathrm{C}-\mathrm{Al}_{2} \mathrm{O}_{3}$. For $\mathrm{AlN}$ on $\mathrm{C}-\mathrm{Al}_{2} \mathrm{O}_{3}$ used in this study, deposition time was 10 to $65 \mathrm{~min}$ or the film thickness $\sim 30$ to $200 \mathrm{~nm}$.

A typical RBS of AlN on $\mathrm{R}-\mathrm{Al}_{2} \mathrm{O}_{3}$ is shown in Figure 2. Similar RBS spectra were obtained for $\mathrm{AlN}$ on $\mathrm{SiO}_{2}$ and $\mathrm{C}-\mathrm{Al}_{2} \mathrm{O}_{3}$. The film thickness was deduced from the $\mathrm{N}$-width illustrated in Figure 2. The thickness derived from RBS and XRD results are summarized in Tables 1 and 2 for $\mathrm{AlN}$ on $\mathrm{R}-\mathrm{Al}_{2} \mathrm{O}_{3}$ and $\mathrm{SiO}_{2}$. Here, accuracies of 
Table 1. A summary of RBS (thickness, L) and XRD (intensity, FWHM and a-axis length) characterization of as-deposited

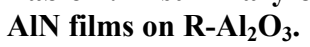

\begin{tabular}{cccccc}
\hline Sample & Deposition Time $(\mathrm{min})$ & $\mathrm{L}(\mathrm{nm})$ & Relative Intensity & FWHM (deg.) & a-axis length $(\mathrm{nm})$ \\
\hline Z1d & 15 & 42.7 & 0.85 & 2.68 & 0.3149 \\
78b & 30 & 95 & 0.002 & 2.22 & 0.3157 \\
$71 \mathrm{a}$ & 30 & 115 & 3.2 & 2.14 & 0.3147 \\
C3d & 45 & 148 & 4.4 & 2.81 & 0.3189 \\
$95 \mathrm{c}$ & 55 & 171 & 1.0 & 2.34 & 0.3177 \\
X6a & 67 & 200 & 2.5 & 2.0 & 0.3149 \\
98a & 55 & 208 & 8.5 & 2.33 & 0.3170 \\
X8h & 100 & 271 & 5.2 & 3.7 & 0.3214 \\
C0f & 120 & 368 & 0.79 & 2.18 & 0.3124 \\
Y6c & 160 & 449 & 10.6 & & \\
\hline
\end{tabular}

Table 2. A summary of RBS (thickness, L) and XRD (intensity, FWHM and c-axis length) characterization of as-deposited AlN films on $\mathrm{SiO}_{2}$.

\begin{tabular}{cccccc}
\hline Sample & Deposition Time $(\mathrm{min})$ & $\mathrm{L}(\mathrm{nm})$ & Relative Intensity & FWHM (deg.) & c-axis length $(\mathrm{nm})$ \\
\hline Z0c & 15 & 37.7 & 0.01 & & 0.0 \\
70c & 30 & 108 & 2.7 & 10 & 0.50764 \\
Z6e & 45 & 148 & 0.54 & 16 & 0.51039 \\
96a & 55 & 167 & 0.32 & & 0.50699 \\
$85 \mathrm{~h}$ & 60 & 184 & 0.08 & 0.50754 \\
85c & 60 & 190 & 0.07 & 8.1 & 0.50685 \\
Y1d & 65 & 199 & 1.8 & 9.3 & 0.50936 \\
89f & 56 & 213 & 0.97 & \\
Z5e & 80 & 233 & 0.016 & & 0.5 \\
Y5a & 100 & 325 & 2.5 & & 0.50866 \\
\hline
\end{tabular}

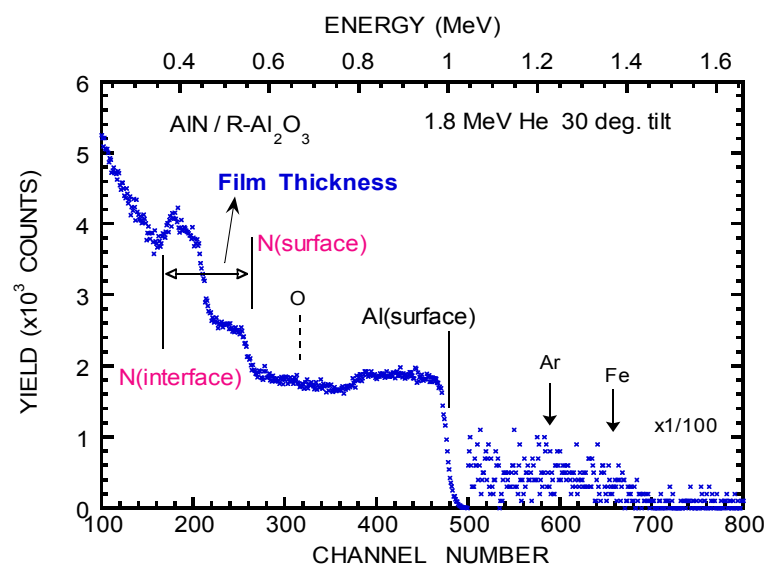

Figure 2. RBS of $\mathrm{AIN}$ on $\mathrm{R}-\mathrm{Al}_{2} \mathrm{O}_{3}$ (sample 98a in Table 1). The spectra were obtained using $1.8 \mathrm{MeV} \mathrm{He}$, and incident and outgoing angle are $30^{\circ}$ and $50^{\circ}$ measured from surface normal. Energies of He scattered from $\mathrm{Al}$ and $\mathrm{N}$ located at surface and interface are indicated by vertical lines. Ar and Fe impurities are also indicated.

thickness, XRD intensity, FWHM and axis length are estimated to be $10 \%, 20 \%, 3 \%$ and $0.3 \%$, respectively. The composition appears to be nearly stoichiometric
$(\mathrm{N}: \mathrm{Al}=1: 1)$, within the RBS accuracy of $10 \%$. One sees some impurities in the RBS spectra and tentatively identified as $\mathrm{Fe}$ (main component of stainless steel) and $\mathrm{Ar}$, considering that stainless steel is the main material of RF-sputter deposition chamber and $\mathrm{Ar}$ gas has been often employed. We find that for $16 \mathrm{AlN}$ films on $\mathrm{R}-\mathrm{Al}_{2} \mathrm{O}_{3}$ including those given in Table 1, Fe and Ar impurity concentration relative to $\mathrm{Al}$ concentration ranges from $0.04 \%-0.1 \%$ and $0.045 \%-0.14 \%$, respectively. Slightly larger amounts (Fe: $0.05 \%-0.17 \%$, and Ar: $0.4 \%$ $0.17 \%$ ) were observed for AlN on $\mathrm{SiO}_{2}$. Similar amounts of $\mathrm{Ar}$ and $\mathrm{Fe}$ impurities were detected for $\mathrm{AlN}$ on $\mathrm{C}$ $\mathrm{Al}_{2} \mathrm{O}_{3}$. No noticeable relation is found between the $\mathrm{Fe}$ impurity concentration and the XRD intensity, and between the Ar impurity concentration and the XRD intensity. NRA was performed for the films on $\mathrm{R}-\mathrm{Al}_{2} \mathrm{O}_{3}$ given in Table 1 and shows that the areal density of $\mathrm{C}$ (no information of depth profile is available because of poor depth resolution of the NRA) on/in AlN films ranges from 5 to $18 \times 10^{15} \mathrm{~cm}^{-2}$, larger than $\sim 3 \times 10^{15} \mathrm{~cm}^{-2}$ for virgin $\mathrm{R}-\mathrm{Al}_{2} \mathrm{O}_{3}$ substrate. NRA also shows that the areal density of $\mathrm{O}$ near the film surface ranges from $8-16 \times$ $10^{15} \mathrm{~cm}^{-2}$. Similar amounts of $\mathrm{C}$ and $\mathrm{O}$ were detected for 
AlN on $\mathrm{SiO}_{2}\left(\mathrm{C}: 7\right.$ to $15 \times 10^{15} \mathrm{~cm}^{-2}$, O near the film surface: 6 to $\left.17 \times 10^{15} \mathrm{~cm}^{-2}\right)$. Again no clear relation is observed between the XRD intensity and $\mathrm{C}$ impurity density, and between the XRD intensity and O impurity density near the film surface. The former result leads to a speculation that the majority of $\mathrm{C}$ impurities are located near the surface. For AlN on $\mathrm{C}-\mathrm{Al}_{2} \mathrm{O}_{3}$, similar amounts of impurities are assumed.

One sees that the XRD intensity does not follow a linear increase with the film thickness for $\mathrm{AlN}$ on $\mathrm{R}-\mathrm{Al}_{2} \mathrm{O}_{3}$ and $\mathrm{SiO}_{2}$ (Tables 1 and 2) and the similar situations is observed for $\mathrm{AlN}$ on $\mathrm{C}-\mathrm{Al}_{2} \mathrm{O}_{3}$. As suggested in [20], $\mathrm{XRD}$ intensity vs stress is shown in Figure 3. Here, the stress is defined by the axis length of the film divided by the bulk value ( 0.31111 and $0.49788 \mathrm{~nm}$ for a- and c-axis [23]) minus unity, assuming that the stress defined above represents the residual-stress as mentioned earlier. Usually, several samples were prepared in the same run. For a particular run for AlN on $\mathrm{R}-\mathrm{Al}_{2} \mathrm{O}_{3}$, having the film thickness around $380 \mathrm{~nm}$, the results of four samples are shown. Accidentally, the sample (COf) given in Table 1 is the poorest in the crystalline quality (XRD intensity is the lowest). As shown in Figure 3, it is found that the XRD intensity decreases with increasing the stress, except for the thinnest films, regardless of the substrates, as observed for AlN with c-axis orientation on $\mathrm{Si}(111)$ substrate [20]. These results indicate no relaxation of the stress regardless of the film thickness and substrates, implying that the stress is an import factor determining the crystalline quality, and that a simple explanation by misfit (lattice parameter mismatch between the film and substrate) is not applicable to the present results. Introduction of the stress might be affected by $\mathrm{O}, \mathrm{C}$ and possibly $\mathrm{H}$ impurities in the film as well as substrate surface condition, and these are to be investigated.

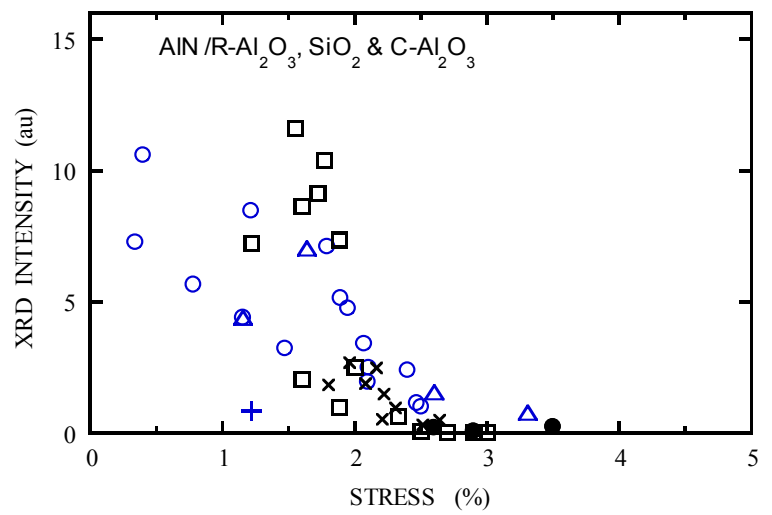

Figure 3. XRD intensity vs stress for $\mathrm{AIN}$ films on $\mathbf{R}-\mathrm{Al}_{\mathbf{2}} \mathrm{O}_{\mathbf{3}}$ $(\mathrm{O}, \Delta,+), \mathrm{SiO}_{2}(\mathrm{x})$ and $\mathrm{C}-\mathrm{Al}_{2} \mathrm{O}_{3}(\square, \bullet)$. Data $(\Delta)$ are taken for the films prepared in the same run having the thickness of $\sim 380 \mathrm{~nm}$. Datum indicated by + is the result of the thinnest film (sample of $\mathrm{Z1d}$ in Table 1). For $\mathrm{AIN}$ on $\mathrm{C}-\mathrm{Al}_{2} \mathrm{O}_{3}$, film thickness is less than $50 \mathrm{~nm}(\bullet)$ and $90-200 \mathrm{~nm}(\square)$.

\subsection{Surface Morphology, Optical Absorption and High-Energy Ion Irradiation Effects}

Surface morphology is mainly studied for AlN on R$\mathrm{Al}_{2} \mathrm{O}_{3}$ and $\mathrm{SiO}_{2}$. An AFM image of as-deposited AlN film on $\mathrm{R}-\mathrm{Al}_{2} \mathrm{O}_{3}$ is shown in Figure 4(a). One sees that a column with c-axis orientation lays down parallel to the surface. The grain is often non-spherical, columnar and thus the grain size is less well-defined. It appears that the smaller size of columnar grains ranges from 20 to $40 \mathrm{~nm}$ and their length extends to over $250 \mathrm{~nm}$, as shown in Figure 5(a) and surface smoothness (or roughness) in terms of root mean square (RMS) of the surface height ranges from $0.2-3 \mathrm{~nm}$ as shown in Figure 5(b). It appears that surface roughness increases linearly with the film thickness for $\mathrm{AlN}$ on $\mathrm{R}-\mathrm{Al}_{2} \mathrm{O}_{3}$. Figure 4(b) shows an AFM image of AlN film on $\mathrm{R}-\mathrm{Al}_{2} \mathrm{O}_{3}$ after irradiation of $90 \mathrm{MeV} \mathrm{Ni}$ ions at $1 \times 10^{13} \mathrm{~cm}^{-2}$, and ion irradiation effects will be described later. Figures 4(c) and (d) show AFM images of AlN on $\mathrm{SiO}_{2}$ and $\mathrm{C}-\mathrm{Al}_{2} \mathrm{O}_{3}$ and cross section of grains on these substrates is nearly circular. The grain size of $\mathrm{AlN}$ on $\mathrm{SiO}_{2}$ is $10-40 \mathrm{~nm}$ (Figure 5(a)) and RMS is $0.8-2 \mathrm{~nm}$ (Figure 5(b)). Grain size is $\sim 20 \mathrm{~nm}$ for AlN on $\mathrm{C}_{-} \mathrm{Al}_{2} \mathrm{O}_{3}$ shown in Figure 4(d), where RMS is $0.36 \mathrm{~nm}$. In this study, surface smoothness is the best for $\mathrm{AlN}$ on $\mathrm{C}-\mathrm{Al}_{2} \mathrm{O}_{3}$ and poorest on $\mathrm{SiO}_{2}$. For $90 \mathrm{MeV} \mathrm{Ni}$ ion irradiation on $\mathrm{AlN}$ on $\mathrm{R}-\mathrm{Al}_{2} \mathrm{O}_{3}$ at $10^{13} \mathrm{~cm}^{-2}$, change was not observed in RBS (see Figure 2) and AFM image remained nearly the same as before irradiation, but surface roughness (RMS) slightly decreases (from $0.75 \mathrm{~nm}$ to $0.55 \mathrm{~nm}$ ).

For $\mathrm{AlN}$ on $\mathrm{R}-\mathrm{Al}_{2} \mathrm{O}_{3}$ under irradiation with $90 \mathrm{MeV} \mathrm{Ni}$ ions up to $6 \times 10^{13} \mathrm{~cm}^{-2}$, which appears to cause significant inelastic-collision-effects [25], no change in the axis-length was observed within $0.1 \%$, i.e., no stress relaxation by ion irradiation and the XRD intensity at the fluence of $\sim 6 \times 10^{13} \mathrm{~cm}^{-2}$ decreases to half of that of as-deposited film. No appreciable but slight (several \%) reduction in FWHM of the XRD rocking curve was observed at $\sim$ around $10^{13} \mathrm{~cm}^{-2}$.

Optical absorption spectra of AlN on $\mathrm{R}-\mathrm{Al}_{2} \mathrm{O}_{3}$ are shown in Figure 6. The bandgap as of deposited film is obtained to be $5.7 \mathrm{eV}$ in reasonable agreement with the reported value of $\sim 6.0 \mathrm{eV}[1,2]$. Optical absorption has little changed, except for the wavelength below $300 \mathrm{~nm}$ (Figure 6) and the bandgap decreases by $\sim 0.2 \mathrm{eV}$. Similarly, the bandgap of $5.7 \mathrm{eV}$ is obtained for as-deposited AlN film on $\mathrm{SiO}_{2}$.

\section{Summary}

We have presented characterization of AlN films on $\mathrm{R}-\mathrm{Al}_{2} \mathrm{O}_{3}, \mathrm{SiO}_{2}$-glass and $\mathrm{C}-\mathrm{Al}_{2} \mathrm{O}_{3}$ substrates by means of $\mathrm{XRD}$, ion beam technique, AFM and optical absorption. Good quality of AIN films with exceptional orientation 


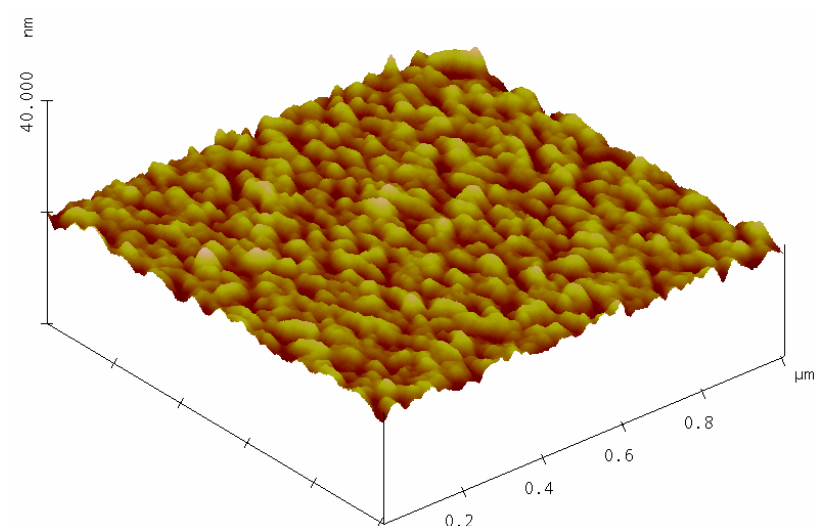

(a)

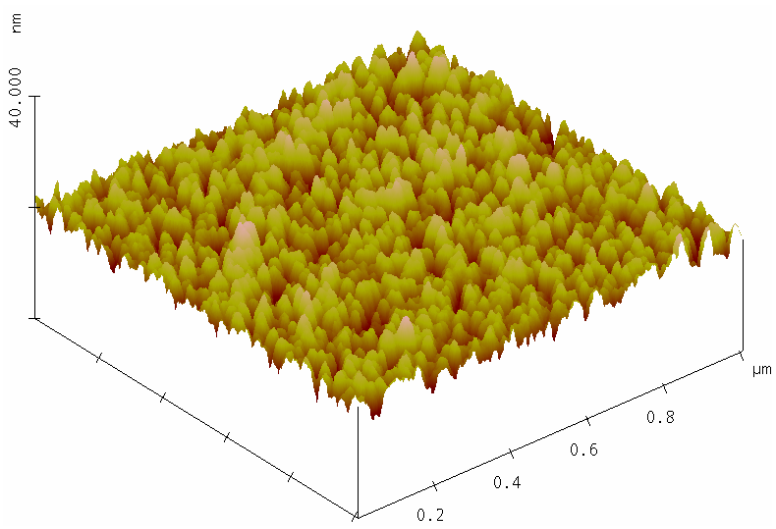

(c)

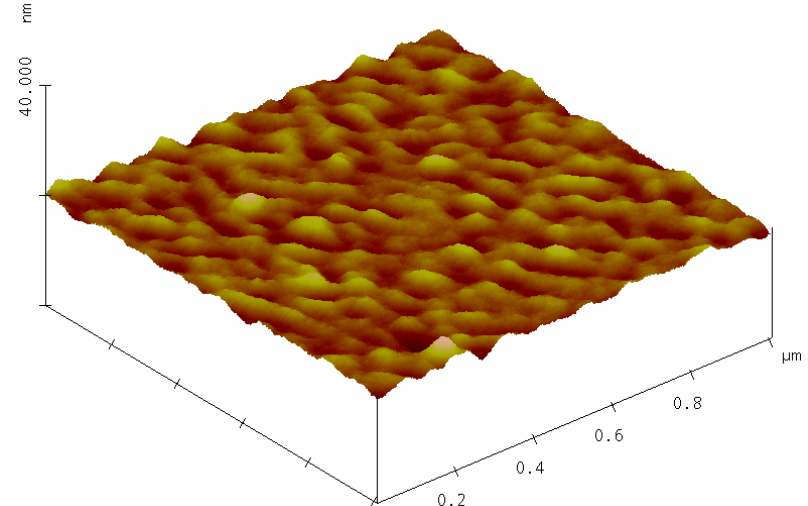

(b)

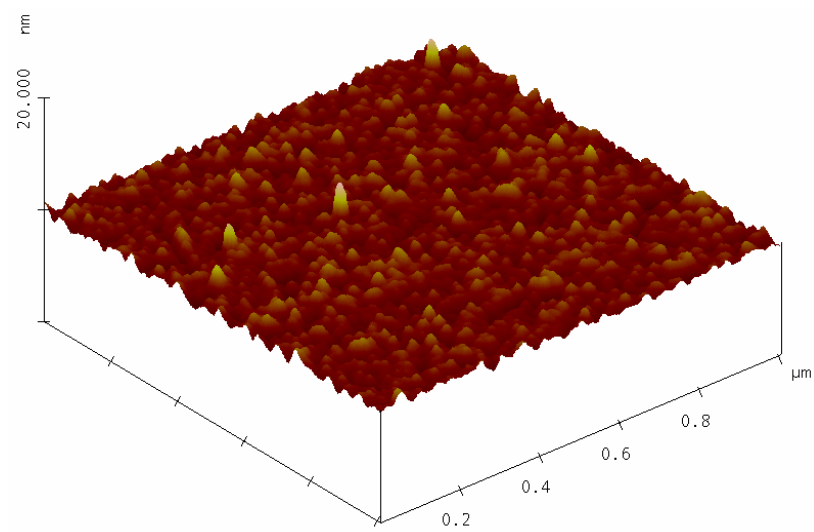

(d)

Figure 4. (a) AFM image of as-deposited AIN film on $\mathrm{R}_{-} \mathrm{Al}_{2} \mathrm{O}_{3}$. Deposition time was 55 min. Surface roughness (RMS) is 0.75

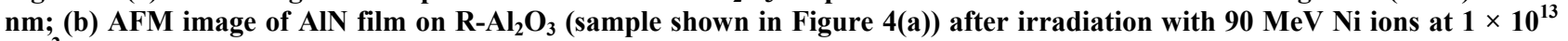
$\mathrm{cm}^{-2}$; (c) AFM image of as-deposited AIN film on $\mathrm{SiO}_{2}$ (sample: $85 \mathrm{~h}$ in Table 2). Deposition time was 60 min. Surface roughness (RMS) is $1.7 \mathrm{~nm}$; (d) AFM image of as-deposited $\mathrm{AIN}$ film on $\mathrm{C}-\mathrm{Al}_{2} \mathrm{O}_{3}$. Deposition time was 60 min. Surface roughness (RMS) is $0.36 \mathrm{~nm}$.

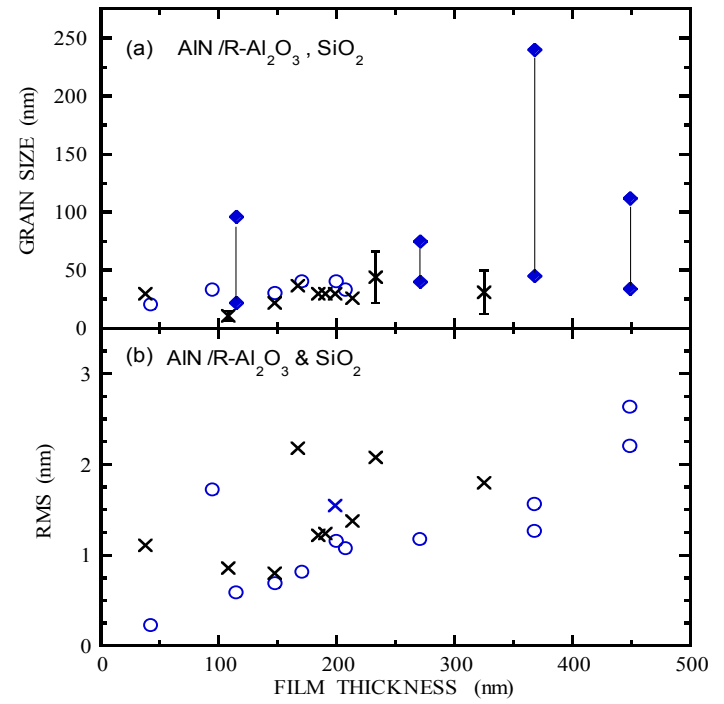

Figure 5. (a) Grain size (nm) vs film thickness (nm) for AIN on $\mathrm{R}-\mathrm{Al}_{2} \mathrm{O}_{3}(\mathrm{O}, \diamond)$ and $\mathrm{SiO}_{2}(\mathrm{x})$ and $(\mathrm{b})$ surface roughness in terms of root mean square (RMS) vs film thickness for $\mathrm{AlN}$ on $\mathrm{R}-\mathrm{Al}_{2} \mathrm{O}_{3}(\mathrm{O})$ and $\mathrm{SiO}_{2}(\mathrm{x})$.

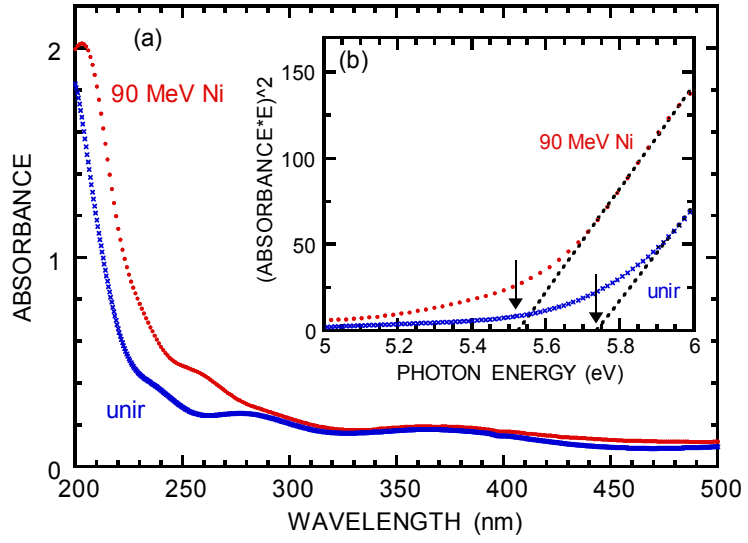

Figure 6. Optical absorption spectra before and after irradiation with $90 \mathrm{MeV} \mathrm{Ni}$ ions at $1 \times 10^{13} \mathrm{~cm}^{-2}$. Inset shows the square of absorbance times photon energy vs photon energy, illustrating bandgap determination.

of a-axis orientation has been obtained on $\mathrm{R}-\mathrm{Al}_{2} \mathrm{O}_{3}$ substrate and a correlation is found between the stress and crystalline quality in terms of XRD intensity. Effects of 
irradiation with $90 \mathrm{MeV} \mathrm{Ni}$ ions have been briefly described.

\section{Acknowledgements}

XRD was performed at EcoTopia Science Institute and Radioisotope Research Center, Nagoya University. The authors thank Mr. T. Masuda for technical assistance of ion beam analysis performed at Nagoya University.

\section{REFERENCES}

[1] W. M. Yim, E. J. Stofko, P. J. Zanzucchi, J. I. Pankove, M. Ettenberg and S. L. Gilbert, "Epitaxially Grown AlN and Its Optical Band Gap," Journal of Applied Physics, Vol. 44, No. 1, 1973, pp. 292-296.

doi: $10.1063 / 1.1661876$

[2] C. Ozgit, I. Donmez, M. Alevli and N. Biyikli, "Self-Limiting Low-Temperature Growth of Crystalline AlN Thin Films by Plasma-Enhanced Atomic Layer Deposition," Thin Solid Films, Vol. 520, 2012, pp. 2750-2755. doi:10.1016/j.tsf.2011.11.081

[3] K. M. Taylor and C. Lenie, "Some Properties of Aluminum Nitride," Journal of the Electrochemical Society, Vol. 107, No. 4, 1960, pp. 308-314. doi:10.1149/1.2427686

[4] G. A. Slack, "Nonmetallic Crystals with High Thermal Conductivity," Journal of Physics and Chemistry of Sol$i d s$, Vol. 34, No. 2, 1973, pp. 321-335. doi:10.1016/0022-3697(73)90092-9

[5] Z. An, C. Men, Z. Xu, P. K. Chu and C. Lin, "Electrical Properties of AlN Thin Films Prepared by Ion Beam Enhanced Deposition," Surface \& Coatings Technology, Vol. 196, No. 1-3, 2005, pp. 130-134.

doi:10.1016/j.surfcoat.2004.08.169

[6] X. Song, R. Fu and H. He, "Frequency Effects on the Dielectric Properties of AlN Film Deposited by Radio Frequency Reactive Magnetron Sputtering," Microelectronic Engineering, Vol. 86, No. 11, 2009, pp. 2217-2221. doi:10.1016/j.mee.2009.03.036

[7] W. M. Yim and R. J. Paff, "Thermal Expansion of AlN, Sapphire, and Silicon," Journal of Applied Physics, Vol. 45, No. 3, 1974, pp. 1456-1457. doi:10.1063/1.1663432

[8] S. P. Dodd, G. A. Saunders, M. Cankurtaran and B. James, "Ultrasonic Study of the Elastic and Nonlinear Acoustic Properties of Ceramic Aluminum Nitride," Journal of Materials Science, Vol. 36, No. 3, 2001, pp. 723-729. doi:10.1023/A:1004897126648

[9] I. Yonenaga, "Thermo-Mechanical Stability of WideBandgap Semiconductors: High Temperature Hardness of $\mathrm{SiC}, \mathrm{AlN}, \mathrm{GaN}, \mathrm{ZnO}$ and $\mathrm{ZnSe}$," Physica B: Condensed Matter, Vol. 308-310, 2001, pp. 1150-1152. doi:10.1016/S0921-4526(01)00922-X

[10] A. F. Belyanin, L. L. Bouilov, V. V. Zhirnov, A. I. Kamenev, K. A. Kovalskij and B. V. Spitsyn, "Applications of Aluminum Nitride Films for Electronic Devices," Diamond and Related Materials, Vol. 8, No. 2-5, 1999, pp. 369-372. doi:10.1016/S0925-9635(98)00412-9
[11] M. B. Assouar, O. Elmazria, P. Kirsch, P. Alnot, V. Mortet and C. Tiusan, "High-Frequency Surface Acoustic Wave Devices Based on AlN/Diamond Layered Structure Realized Using E-Beam Lithography," Journal of Applied Physics, Vol. 101, 2007, Article ID: 114507. doi:10.1063/1.2739218

[12] J. Olivares, E. Iborra, M. Clement, L. Vergara, J. Sangrador and A. Sanz-Hervas, "Piezoelectric Actuation of Microbridges Using AlN," Sensors and Actuators A, Vol. 123-124, 2005, pp. 590-595. doi:10.1016/j.sna.2005.03.066

[13] F. A. Ponce and D. P. Bour, "Nitride-Based Semiconductors for Blue and Green Light-Emitting Devices," Nature, Vol. 386, 1997, pp. 351-359. doi:10.1038/386351a0

[14] X. Ni, L. Zhu, Z. Ye, Z. Zhao, H. Tang, W. Hong and B. Zhao, "Growth and Characterization of GaN Films on Si(111) Substrate Using High-Temperature AIN Buffer Layer," Surface \& Coatings Technology, Vol. 198, No. $1-3,2005$, pp. $350-353$. doi:10.1016/j.surfcoat.2004.10.073

[15] V. Venkatachalapathy, A. Galeckas, I.-H. Lee and A. Y. Kuznetsov, "Engineering of Nearly Strain Free ZnO Films on Si(111) by Tuning AlN Buffer Thickness," Physica B: Condensed Matter, Vol. 407, 2012, pp. 1476-1480. doi:10.1016/j.physb.2011.09.065

[16] S. Raghavan and J. M. Redwing, "In Situ Stress Measurements during the MOCVD Growth of AlN Buffer Layers on (111) Si Substrates," Journal of Crystal Growth, Vol. 261, No. 2-3, 2004, pp. 294-300. doi:10.1016/j.jcrysgro.2003.11.020

[17] N. Onojima, J. Suda and H. Matsunami, "Lattice Relaxation Process of AlN Growth on Atomically Flat $6 \mathrm{H}-\mathrm{SiC}$ Substrate in Molecular Beam Epitaxy," Journal of Crystal Growth, Vol. 237-239, 2002, pp. 1012-1016. doi:10.1016/S0022-0248(01)02118-2

[18] S.-H. Lee, K. H. Yoon, D.-S. Cheong and J.-K. Lee, "Relationship between Residual Stress and Structural Properties of AlN Films Deposited by r.f. Reacrive Sputtering," Thin Solid Films, Vol. 435, No. 1-2, 2003, pp. 193-198. doi:10.1016/S0040-6090(03)00353-5

[19] J. Keckes, S. Six, W. Tesch, R. Resel and B. Rauschenbach, "Evaluation of Thermal and Growth Stresses in Heteroepitaxial AIN Thin Films Formed on (0001) Sapphire by Pulsed Laser Ablation," Journal of Crystal Growth, Vol. 240, No. 1-2, 2002, pp. 80-86. doi:10.1016/S0022-0248(02)00877-1

[20] N. Matsunami, S. Venkatachalam, M. Tazawa, H. Kakiuchida and M. Sataka, "Ion Beam Characterization of rfSputter Deposited AIN Films on Si(111)," Nuclear Instruments Methods B, Vol. 266, No. 8, 2008, pp. 15221526. doi:10.1016/j.nimb.2007.12.086

[21] N. Matsunami, T. Shimura, M. Tazawa, T. Kusumori, H. Kakiuchida, M. Ikeyama, Y. Chimi and M. Sataka, "Modifications of AIN Thin Films by Ions," Nuclear Instruments Methods B, Vol. 257, No. 1-2, 2007, pp. 433-437. doi:10.1016/j.nimb.2007.01.043

[22] J. F. Ziegler, J. P. Biersack and U. Littmark, "The Stopping and Range of Ions in Solids," Pergamon Press, New York, 1985. 
[23] W. Martienssen and H. Warlimont, "Handbook of Condensed Matter and Materials Data," Springer, Berlin, 2005. doi:10.1007/3-540-30437-1

[24] J. X. Zhang, H. Cheng, Y. Z. Chen, A. Uddin, S. Yuan, S. J. Geng and S. Zhang, "Growth of AlN Films on Si(100) and $\mathrm{Si}(111)$ Substrates by Reactive Magnetron Sputter- ing," Surface Coating \& Technology, Vol. 198, No. 1-3, 2005, pp. 68-73. doi:10.1016/j.surfcoat.2004.10.075

[25] N. Matsunami, M. Sataka, S. Okayasu and M. Tazawa, "Electronic Sputtering of Nitrides by High-Energy Ions," Nuclear Instruments Methods B, Vol. 256, No. 1, 2007, pp. 333-336. doi:10.1016/i.nimb.2006.12.022 